\title{
CYTOKINE RECEPTOR EXPRESSION IN HUMAN LYMPHOID TISSUE: ANALYSIS BY FLUORESCENCE MICROSCOPY
}

\author{
HEDDY ZOLA*, JODIE RIDINGS*, HELEN WEEDON*, MICHAEL FUSCO*, ROGER W. BYARD $\$$, \\ PETER J. MACARDLE $\$$ \\ * Child Health Research Institute and ${ }^{\$}$ Department of Paediatrics, Women's and Children's Hosptial, and \\ $\$$ Flinders Medical Centre, Adelaide, South Australia
}

\begin{abstract}
SUMMARY
A highly-sensitive flourescence method, capable of detecting cytokine receptors present at low concentrations (around 100 molecules per cell) by flow cytometry, was adapted for use on tissue sections. This method was used to examine the expression of several cytokine receptors in lymphoid tissues. IL-2 receptors were distributed broadly, with higher concentrations in T cell areas. IL-1 receptor Type 1 was detected in $\mathrm{T}$ cell areas and in the follicular mantle, and was strongly expressed on vascular endothelium. IL-6 receptor was found at very low concentration, both within and outside germinal centres. The gp 130 molecule, which is involved in the functional receptor complex for IL-6 and several other cytokines, was present at higher concentrations, particularly in the germinal centre. Analysis of receptor expression in secondary lymphoid tissue provides evidence bearing on the physiological roles of cytokines, as these tissues contain cells at various stages of physiological activation located in well-defined functional zones.
\end{abstract}

KLYWORDS Cytokine receptors Interleukin receptors Tissue staining Cy3 fluorescence

\section{INTRODUCTION}

Cytokines control many aspects of the immune and haematopoietic systems, including the production, proliferation, differentiation, activation and migration of lymphoid and myeloid cells. Cytokine-responsive cells bear specific cytokine receptors. These are often two- or three-chain structures, with one chain interacting specifically with a single cytokine whilst the second chain, which usually confers high affinity on the interaction and transduces signals to the cell, may be shared by several cytokines (Taga and Kishimoto, 1992; Kondo et al., 1993; Noguchi et al., 1993).

Analysis of cytokine receptor expression by lymphoid and myeloid cell populations is useful in understanding the details of cytokine action, and may shed light on pathological as well as physiological processes. There have been many studies reporting cytokine receptor expression on circulating lymphocytes, and other studies reporting soluble receptor levels in the circulation, in health and in a variety of pathological conditions (for a review and commentary, see Zola, 1992 and 1994). However, studies

Correspondence to: Prof. Heddy Zola, Deputy Director, Child Health Research Institute, Women's and Children's Hospital, North Adelaide SA5006, Australia. Tel.: 6182047015 ; Fax: 6182390267. 
of cytokine receptor expression in secondary lymphoid tissue have been limited. A number of immunohistochemical studies of cytokine receptor antibodies were presented at the 5th International Leucocyte Typing Workshop (Autschbach et al., 1993; De Weger et al., 1993; Berti et al., 1993; Zola et al., 1993d). These studies produced valuable results, but a common finding was that reactivity was variable and generally weak, presumably because of the low levels of cytokine receptor expression (Autschbach et al., 1993). Tissue studies are needed to further elucidate cytokine function, as secondary lymphoid tissues are the site of important immunological processes, such as cognate $\mathrm{T}$ cell/B cell interaction and germinal centre (GC) reactions. Furthermore, the studies need to be done on tissue sections and not just on cell suspensions, in order to preserve the spatial relationships between cells, which are essential for in vivo immune responses.

Cytokines can mediate their effects on cells which bear very low concentrations of receptor (ranging from 10 to a few hundred molecules per cell), while conventional staining techniques detect molecules present at concentrations of several thousand per/ cell (Zola, 1994; Zola et al., 1990b). For example, IL-1 acts on thymocytes expressing less than 100 molecules of receptor (Dower et al., 1985), while IL-4 acts on B cells expressing around 400 molecules of receptor per cell (Lowenthal et al., 1988). This has necessitated the development of fluoresence staining and flow cytometric methods capable of high sensitivity in order to examine cytokine receptor expression by lymphoid functional sub-populations (Zola et al., 1989, 1990b; Olweus et al., 1993; Coventry et al., 1994; Zola, 1995).

In the current study we adapted our high-sensitivity flow cytometric procedures to microscopy, and examined the expression of cytokine receptors in solid tissue.

\section{MATERIALS AND METHODS}

Monoclonal antibodies. The monoclonal antibodies against cytokine receptors are described in Table 1. Additional monoclonal antibodies used were: anti-IgD: HB70 (ATCC) (Kuritani and Cooper, 1982); CD19: FMC63 (Zola et al., 1990a); CD3: OKT3 (ATCC) (Kung et al., 1979) CD38-FITC (PharMingen, San Diego, Ca.).

Tissue preparing and staining. Lymphoid tissue was obtained fresh and cut into blocks $\left(5-10 \mathrm{~mm}^{3}\right)$ which were snap-frozen in OCT compound (Miles Laboratories, Elkhart, In.). Frozen tissue blocks were stored at $80^{\circ} \mathrm{C}$. Cryostat sections $(6 \mu \mathrm{m})$ were placed on gelatin-coated slides and air-dried overnight, to ensure adherence to the slide. A wax pen was used to draw a circle round the sections, to contain the reagents on the slide. Sections were blocked with $3 \%$ BSA in tris-buffered saline (TBS) for $30 \mathrm{~min}$. All incubations were performed at room temperature in a humidified chamber, and were followed by washing with stirring for $5 \mathrm{~min}$ in TBS containing 1\% BSA. After each wash, excess liquid was removed by gentle blotting with paper tissue, immediately before the addition of the next reagent (to avoid drying-out).

Monoclonal antibody $(100 \mu \mathrm{L})$ was placed on the specimen, at a dilution (in TBS/ $1 \%$ BSA) shown by preliminary titration to give optimal staining with minimal background staining. This was usually a $10-20$-fold lower concentration than used for flow cytometric analysis. The slides were incubated as described and then washed twice. Bound antibody was detected by three different methods, which were compared for sensitivity. 
Table 1. Monoclonal antibodies against cytokine receptors used in this study.

\begin{tabular}{lllll}
\hline Receptor & CD number & Antibody & Ig Type & Source/reference \\
\hline IL-1 type 1 & CD121a & 4C1 & Rat IgG2a & PharMingen \\
IL-2 $\alpha$ (p55) & CD25 & 7G7B6 & Mouse IgG2a & Rubin et al. (1985) \\
IL-2 $\beta($ p75) & CD122 & Mik $\beta 1$ & Mouse IgG2a & Tsudo et al. (1989) \\
IL-2 $\gamma($ p64) & Not clustered & TUGh4 & Rat IgG2b & Ishii et al. (1994) \\
IL-4 & CDw124 & h-IL-4R M57 & Mouse IgG1 & LTV* \\
IL-6 (p80) & CD126 & MT18 & Mouse IgG2b & LTV \\
gp130 & CDw130 & AM64 & Mouse IgG & LTV \\
IL-7 & CDw127 & h-IL-7R M20 & Mouse IgG1 & LTV \\
TNF Type 1 & CD120a & htr-9 & Mouse IgG1 & LTV \\
TNF Type 2 & CD120b & utr-1 & Mouse IgG1 & LTV \\
c-kit & CD117 & YB5B8 & Mouse IgG1 & LTV \\
\hline
\end{tabular}

* LTV: Leucocyte Typing V: 5th International Workshop on Human Leucocyte Differentiation Antigens.

Three-stage immunofluorescence method. Bound monoclonal antibody was detected with biotinylated horse anti-mouse Ig (Vector Laboratories, Burlingame, Ca., catalog \# BA-2000) $(100 \mu \mathrm{L})$. This reagent required absorption with tonsil cells to reduce nonspecific staining. Absorption was carried out with $10^{8}$ fresh or cryopreserved tonsil cells per $\mathrm{mL}$ of antibody at $1 / 100$ dilution, for $1 \mathrm{hr}$ on ice, with occasional mixing. Preliminary titration indicated optimal staining at $1 / 250$ dilution (i.e. $1 / 2.5$ of the absorbed material). Slides were incubated for $1 \mathrm{hr}$ and washed as described, and the bound biotin was then visualised using Cy3-streptavidin (Jackson ImmunoResearch, West Grove, Pa., catalog \# 016-160-084), 100 $\mathrm{LL}$ of a 1/500 dilution. Slides were again incubated and washed as above, after which excess buffer was removed by gently blotting with tissue paper. Slides were mounted in $90 \%$ glycerol in phosphate-buffered saline, containing DABCO to reduce fading.

Two-stage immunofluorescence method. This method was similar to the three-stage method, except that bound monoclonal antibody was detected directly using Cy-3-labelled anti-mouse Ig (Jackson ImmunoResearch, West Grove, Pa., catalog \# 115-166-062).

Immunoperoxidase. This method was carried out as described previously (Coventry et al., 1994). The technique is similar in principle to the three-stage method, but utilises enzyme instead of fluorochrome. The reagents used were biotinylated rabbit anti-mouse Ig (Dako, Glostrup, Denmark, catalog \# E354) followed by steptavidin-horseradish peroxidase (Pierce, Rockford, Il., catalog \# 21124).

Fluorescence microscopy. A number of different fluorescence microscopes were used in the course of this study, and significant differences were found in sensitivity. The Cy3 was well visualised using filter blocks intended for use with rhodamine, such as the Leica N2.1 block (excitation filter $515-560 \mathrm{~nm}$, dichroic mirror at $580 \mathrm{~nm}$ and barrier filter at $580 \mathrm{~nm}$ ) or Leica M2 (excitation filter $546 \pm 14 \mathrm{~nm}$, otherwise as N2.1). The choice of lens was important, with immersion lenses of high numerical aperture giving the highest sensitivity. 
Cell suspension studies. Cells in suspension were stained and analysed by flow cytometry as described elsewhere (Zola et al., 1990b; Zola, 1995). For examination in the microscope, stained cells were deposited on slides using a cytocentrifuge.

\section{RESULTS}

\section{Comparison of fluorochromes}

Phycoerythrin. This fluorochrome gives the highest sensitivity by flow cytometry. However, when examined by fluorescence microscopy, PE fluorescence faded within seconds under microscope illumination, making image capture and examination impractical. A number of anti-fading agents were examined, including DABCO, which is effective in reducing fading of fluorescein, and reagents marketed specifically for use with $\mathrm{PE}$ (AF23, AF93, AF113, AF133; Citifluor, Agar Scientific, Stansted, Essex, UK), but fading was still too rapid to allow image capture and examination. Rapid image capture, using a highly-sensitive video camera, was attempted, but it was difficult to focus and select a field for image capture without losing much of the fluorescence. In an attempt to stabilise fluorescence, sections were fixed directly after staining and before mounting. Sections fixed by brief immersion in acetone showed a significant reduction in fading, which was obvious up to $48 \mathrm{hr}$ after staining, but fixing reduced staining intensity, and PE-labelled samples did not appear as bright as samples stained with $\mathrm{Cy} 3$ (see below). A number of variations in fixative and conditions of fixation did not improve the retention of staining.

Cy-3. Cy-3 gave intense red staining that appeared by eye to be as bright as PE staining. Since the extinction coefficient and quantum yield of Cy-3 (130,000 and 0.15) are lower than those of $\mathrm{PE}(2,000,000$ and 0.8$)$ the latter should be capable of giving a much brighter signal, but fading negates the theoretical advantages of PE.

\section{Comparison of staining protocols}

Staining was carried out using two-stage and three-stage protocols as described. Figure 1 and Figure 2 show that staining was brighter using the three-stage protocol.

\section{Sensitivity of the Cy-3 system}

In order to quantify the sensitivity of the Cy-3 system in comparison with the extensively-characterised PE system, samples of cells were stained in suspension with monoclonal antibody followed by biotinylated horse anit-mouse Ig. They were then stained either with PE-streptavidin (Caltag, San Francisco, Ca., catalog \# SA 1004-4) for flow cytometry or $\mathrm{Cy}-3$ streptavidin for cytocentrifugation and microscopy. The cytocentrifuge preparations were examined using alternatively phase contrast (Normarski) and dark-field fluorescence epi-illumination to count the proportion of cells stained. Flow cytometric results are shown in Figure 3, and the proportion of cells counted as positive in the cytocentrifuge preparations are given in the Figure caption for comparison. These results indicate that $\mathrm{Cy}-3$ fluorescence microscopy allows sensitivity approximately equal to that of flow cytometry with PE. X63 is a negative control, while OKT3 is included to check that the number of un-stained cells is not being underestimated in phase-contrast microscopy.

In a separate experiment, tonsil sections were stained by $\mathrm{Cy}-3$ for immunofluorescence and by immunoperoxidase. Results are shown in Figure 4 . The techniques were 

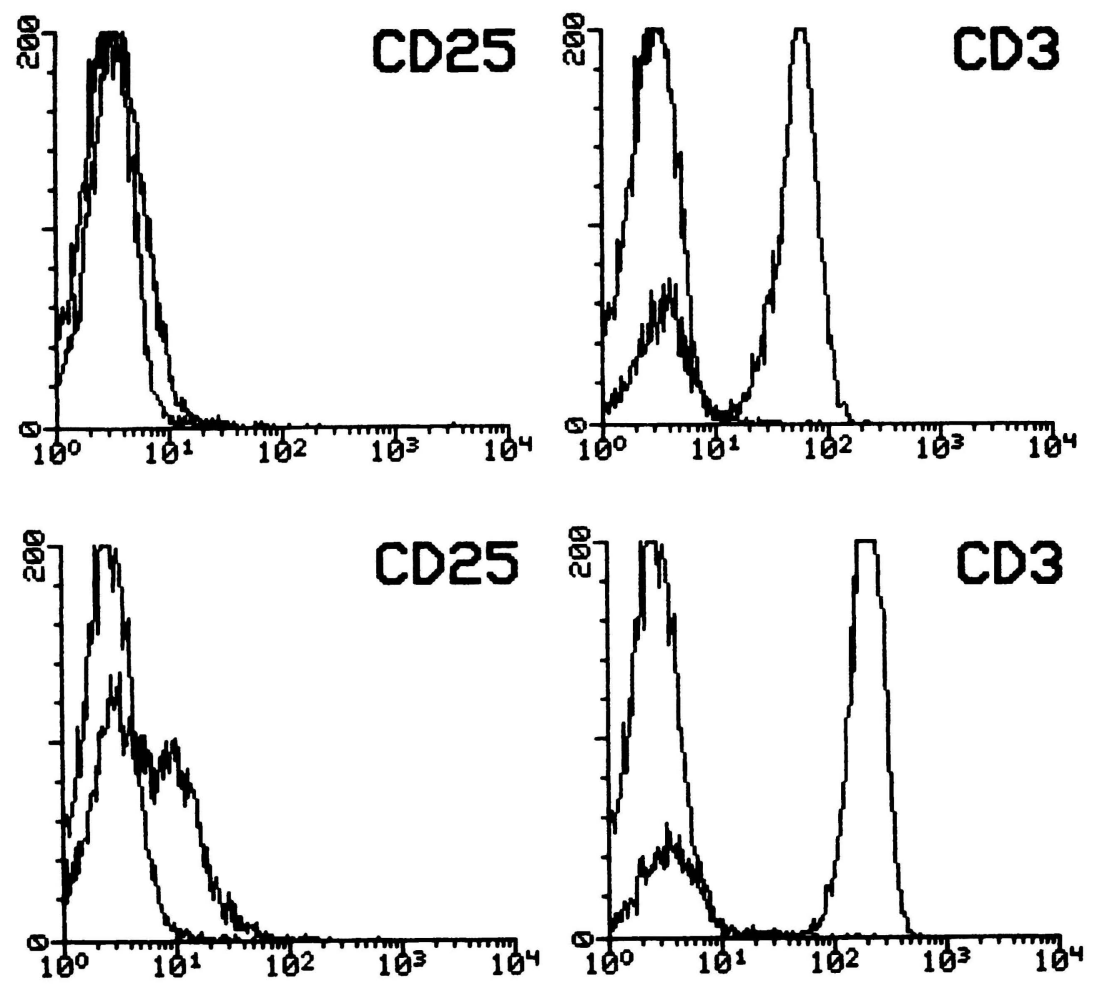

Figure 1. Flow cytometric analysis of $\mathrm{Cy}-3$ fluorescence, comparing two-stage (upper patterns) and threestage (lower patterns) staining with CD3 and CD25. Each histogram is shown superimposed on a negative control antibody. The greater sensitivity of the three-stage method is seen with CD25, which gives a bimodal pattern only in the three-stage method, and with CD3, which shows a brighter peak of positive cells (MFI=206 for the three-stage and 58 for the two-stage method). The negative controls are not increased by the extra layer of staining. Note that Cy-3 is not measured effectively with $488 \mathrm{~nm}$ excitation (compare results to Figure 3 ).

both able to detect a scattering of cells in the $\mathrm{T}$ cell zone expressing relatively high amounts of CD25, but immunofluorescence detected in addition a larger number of weakly-stained cells distributed throughout $\mathrm{T}$ and $\mathrm{B}$ cell areas.

\section{Expression of receptors on lymphoid tissue sections}

The expression of a number of cytokine receptors was examined in human tonsil, spleen, ileum, gut-associated lymph node and appendix. Table 2 summarises the distribution of staining in tonsil, which was studied most extensively ( 3 different tonsils, 5 separate staining experiments), whilst Table 3 summarises the results obtained on a number of different tissues from the same individual. Some of the observations are illustrated in Figure 5 and Figure 4. For some antibodies, the microscope studies were extended using flow cytometric analysis of tonsil cell suspensions.

CD121a (IL-1 receptor Type I) showed strong staining of vascular endothelium in tonsil (Figure 5a), but vascular endothelium in spleen was stained only weakly. In the lymphoid areas, there was moderate staining of cells in the T cell zone (Figure 5a), the follicular mantle appeared slightly brighter than the T cell zone, and GC were usually 


\section{$2(\mathrm{~A})$}

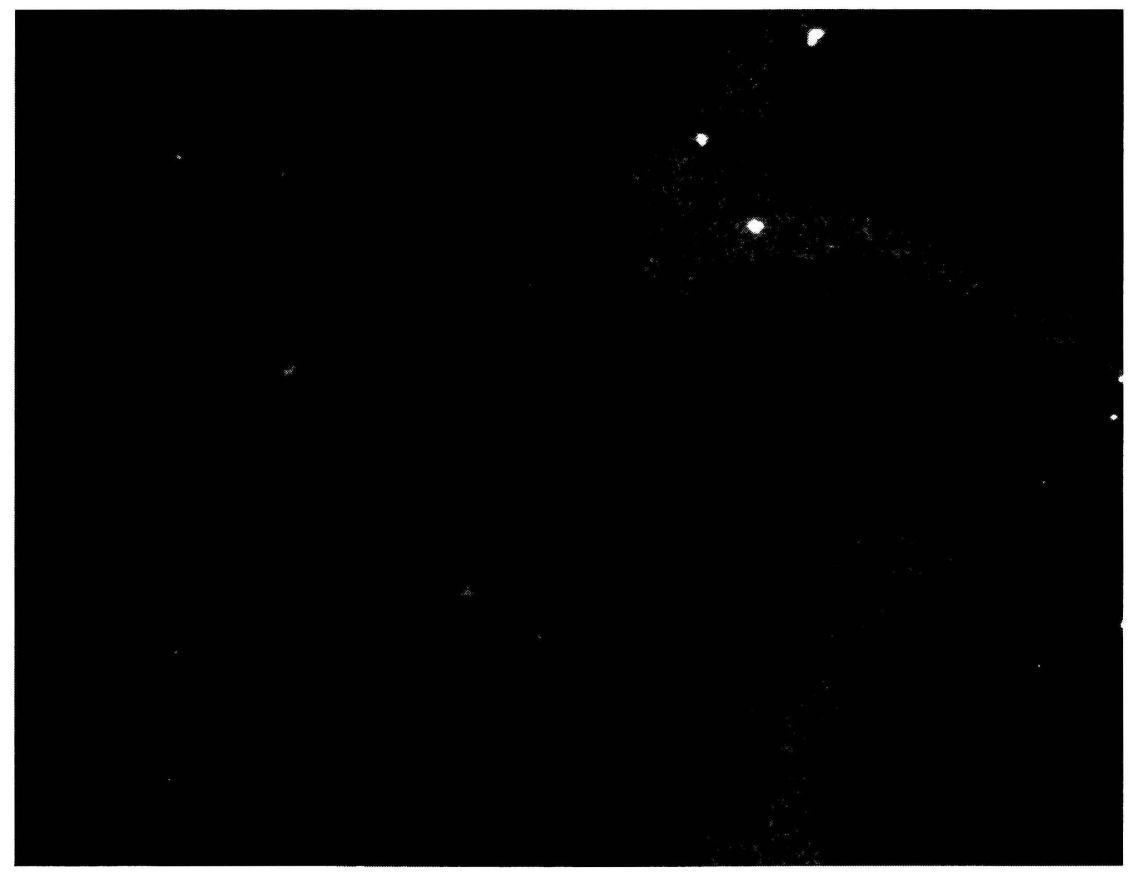

2 (B)

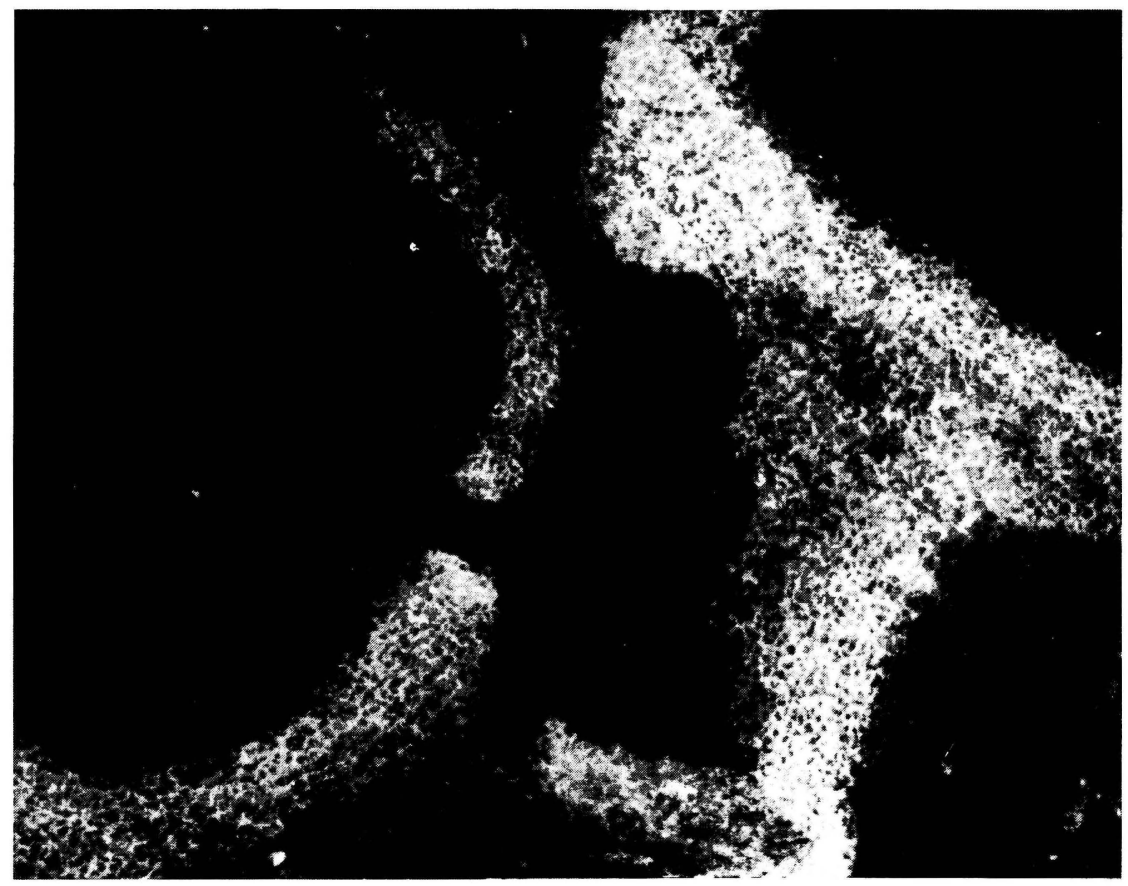

Figure 2. Comparison of two-stage and three-stage staining in tonsil sections. Tonsil was stained with antiIgD by the two procedures; the three-stage procedure (B) showed much brighter staining than the two-stage procedure (A). 


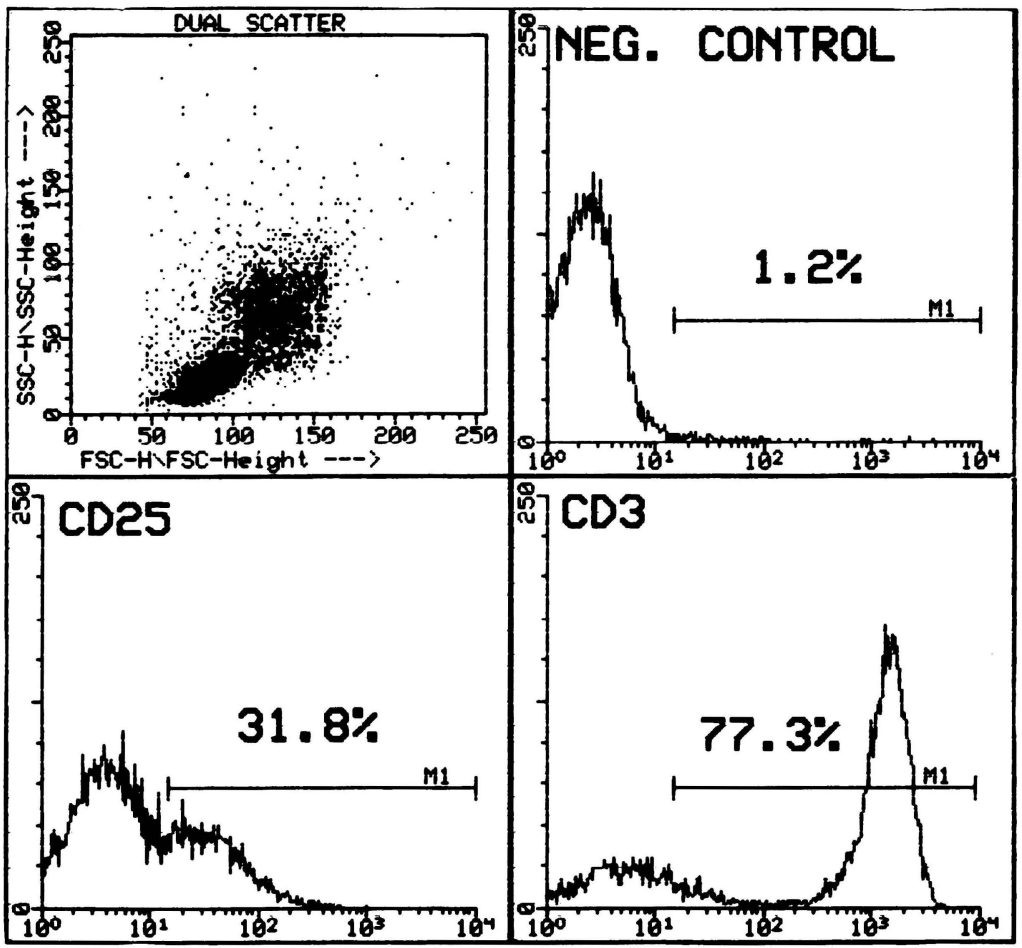

Figure 3. Flow cytometric analysis of normal blood lymphocytes (gated on forward and orthogonal light scatter, top left panel). Staining was with the three-stage method using PE. The \% values represent the proportion of lymphocytes staining with each antibody, and may be compared with the data obtained by microscopy after staining the same samples using the three-stage method with Cy-3: X63: 1.5\%; CD25: 38\%; OKT3: $66 \%$.

Table 2. Cytokine receptor distribution in tonsil sections

Receptor

IL-1 Type 1 (CD121a)

IL-2 $\alpha(\mathrm{CD} 25)$

IL-2 $\beta$ (CD122)

IL-2 $\gamma$ chain

IL-4 (CD 124)

IL-6 (CD126)

gp130 (CD130)

IL-7 (CDw127)

TNF type 1 (CD120a)

TNF type 2 (CD120b)

c-kit (CD117)
Tissue distribution

Vascular endothelium bright, T-cell zone moderate, germinal centre negative Widespread weak staining, brighter $\mathrm{T}$ cell zone; scattered bright cells Weak staining uniformly throughout tissue

Weak staining uniformly throughout tissue

Negative

Very weak staining

Germinal centre stained preferentially, some staining in T cell zone

Very weak staining

Very weak staining

Very weak staining

Scattered bright cells, mainly in connective tissue 
Lymphoid Tissues

\begin{tabular}{|c|c|c|c|c|c|c|c|c|c|c|c|c|c|c|c|c|}
\hline \multirow[t]{2}{*}{ Receptor } & \multicolumn{4}{|c|}{ Spleen } & \multicolumn{3}{|c|}{ Ileum } & \multicolumn{3}{|c|}{ Tonsil } & \multicolumn{3}{|c|}{ Lymph Node (gut) } & \multicolumn{3}{|c|}{ Appendix } \\
\hline & $\mathrm{GC}$ & M & $\mathrm{EF}$ & RED & $\mathrm{GC}$ & M & $\mathrm{EF}$ & GC & $\mathrm{M}$ & $\mathrm{EF}$ & $\mathrm{GC}$ & $\mathrm{M}$ & $\mathrm{EF}$ & $\mathrm{GC}$ & $\mathrm{M}$ & $\mathrm{EF}$ \\
\hline IL-1 type1 (CD121a) & - & - & + & + & - & + & + & - & ++ & ++ & - & + & + & - & + & + \\
\hline $\mathrm{IL}-2 \alpha(\mathrm{CD} 25)$ & 2 & - & + & + & 2 & + & +++ & 2 & + & +++ & 2 & + & +++ & 2 & + & ++ \\
\hline IL-2 $\beta$ (CD122) & \pm & + & + & + & \pm & + & + & \pm & + & + & \pm & + & + & \pm & + & + \\
\hline $\mathrm{Il}-2 \gamma$ & \pm & - & \pm & + & \pm & \pm & - & \pm & - & \pm & \pm & \pm & \pm & \pm & - & + \\
\hline IL-4 (CD124) & - & - & - & - & - & - & - & - & - & - & - & - & - & - & - & - \\
\hline IL-6 (CD126) & \pm & \pm & + & + & - & - & - & - & - & \pm & - & - & \pm & - & - & - \\
\hline gp130 (CD130) & +++ & - & + & +++ & ++ & + & + & ++ & + & + & ++ & + & + & ++ & + & + \\
\hline Il-7 (CD127) & - & - & - & - & - & - & + & - & - & - & - & - & ++ & - & - & - \\
\hline TNF type 1 (CD120a) & \pm & - & - & - & - & - & - & - & - & - & - & - & - & - & - & - \\
\hline TNF type 2 (CD120b) & - & - & \pm & - & - & - & - & - & - & 3 & - & - & \pm & - & - & \pm \\
\hline c-kit (CD117) & \pm & - & \pm & + & - & 1 & 1 & - & 1 & 1 & - & 1 & 1 & - & 1 & 1 \\
\hline
\end{tabular}

$\mathrm{GC}=$ germinal centre

$\mathrm{M}=$ follicular mantle

$\mathrm{EF}=$ extrafollicular area $(\mathrm{T}$ cell zone)

RED $=$ red pulp of spleen (splenic cords)

DEGREE OF STAINING: - negative

$$
\begin{aligned}
& \pm \quad \text { very weak } \\
& +\quad \text { weak } \\
& ++ \text { moderate } \\
& +++ \text { high }
\end{aligned}
$$

$1,2,3$ scattered brightly stained cells in connective tissue ${ }^{1}$ or in germinal centre ${ }^{2}$; a few moderately-stained cells in $\mathrm{T}$ cell area $^{3}$. 
4 (a)

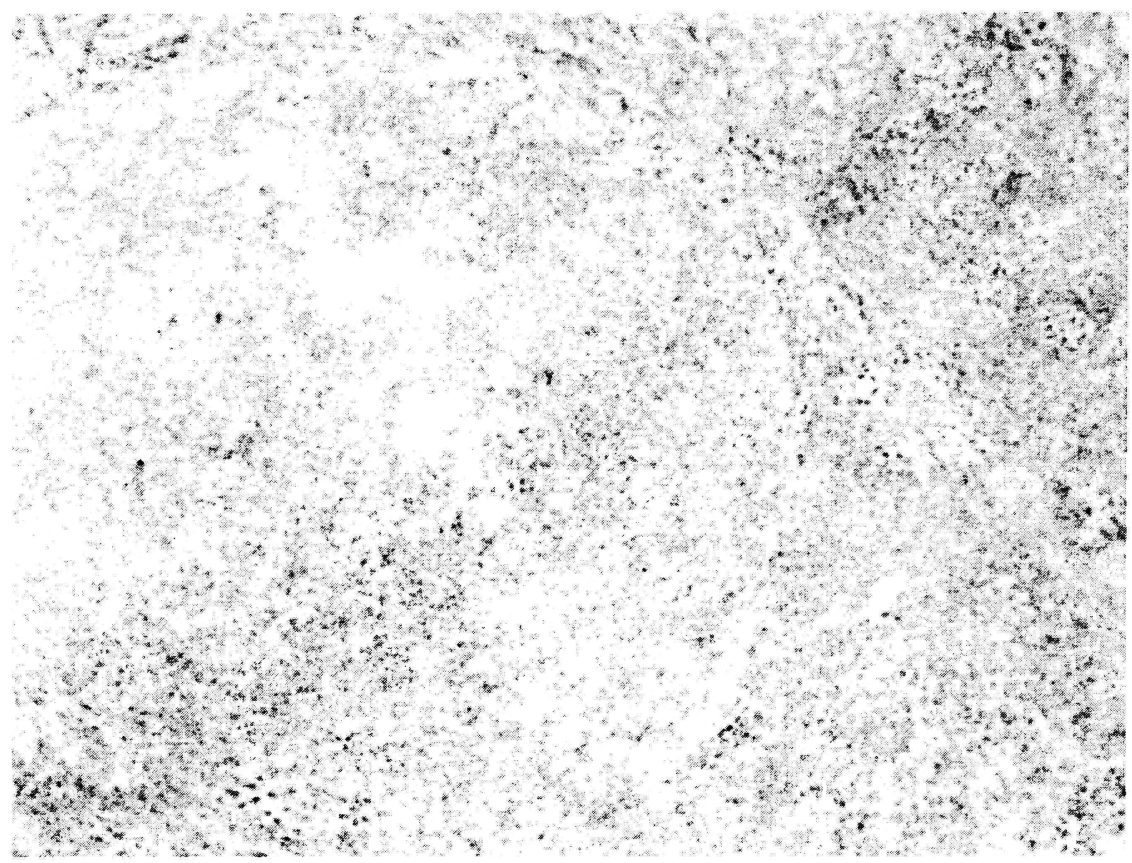

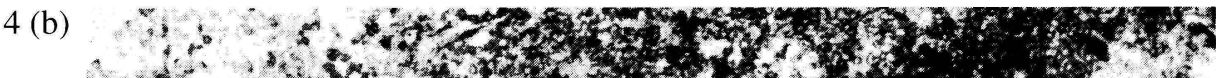
A. 2.

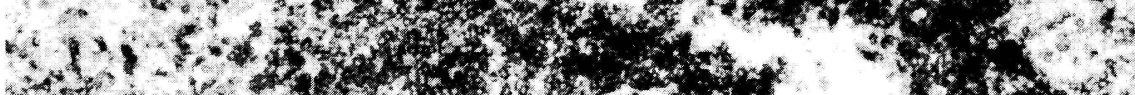

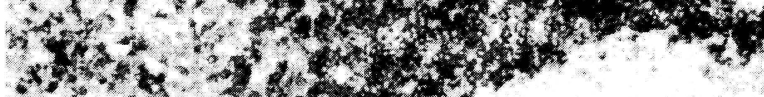

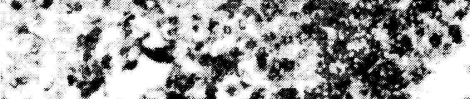

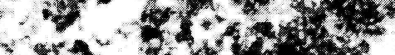

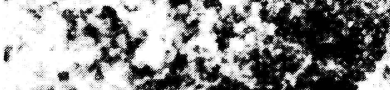

$c^{2}=20^{2+3}+5^{2}$

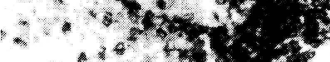

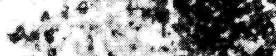

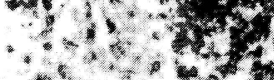

- $1 . \mathrm{r}^{2} \mathrm{H}^{2}$
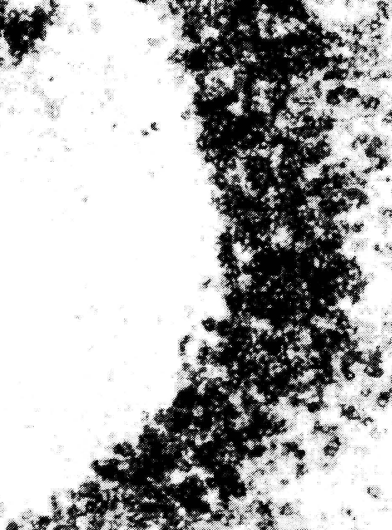

at $x+x^{2}$

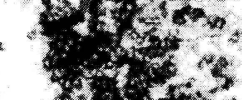


4 (c)

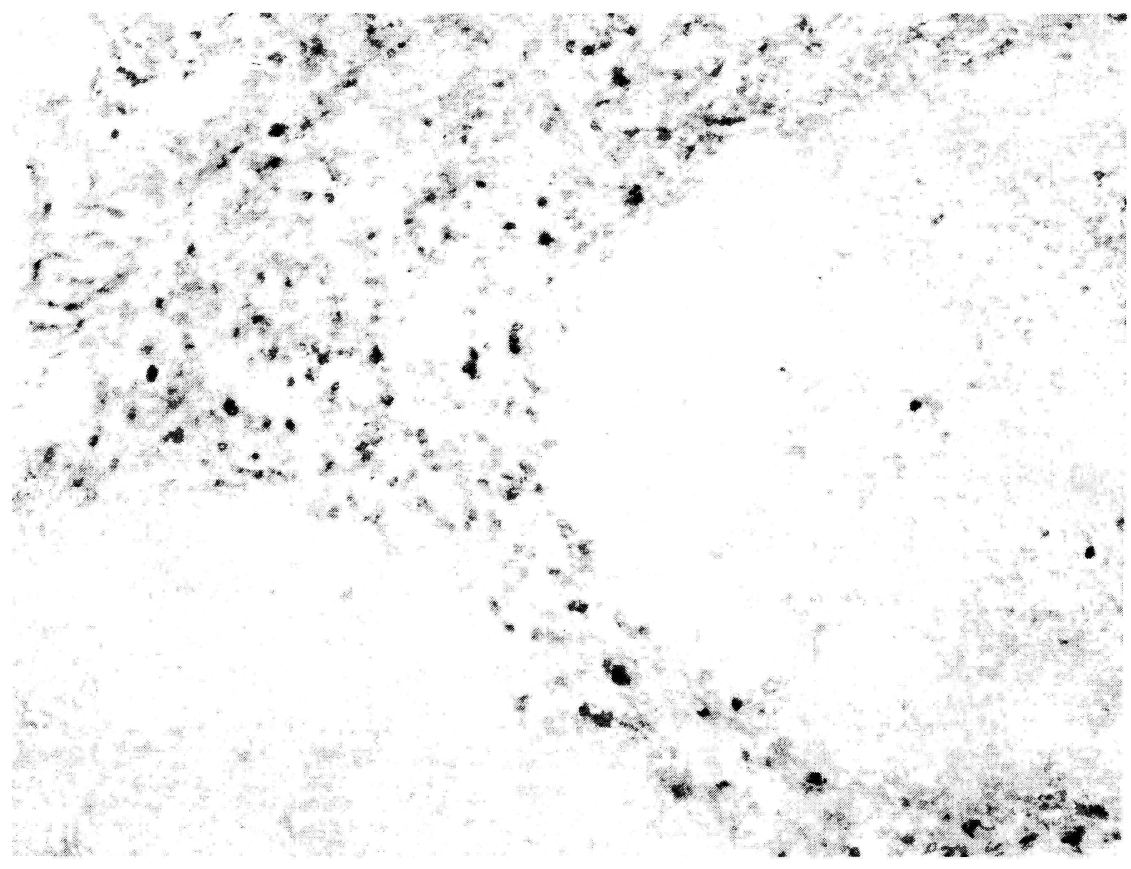

$4(d)$

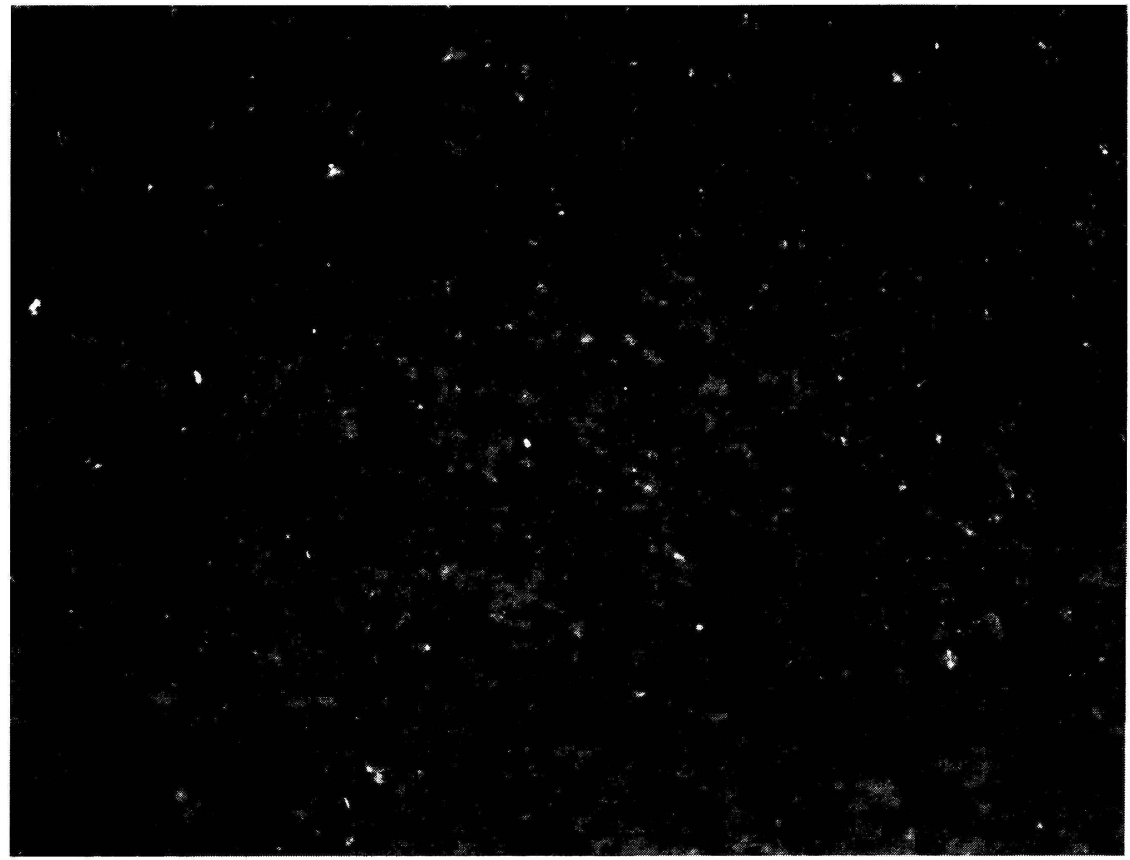

Figure 4. Comparison of immunoperoxidase and immunofluourescence. Figures $4 \mathrm{a}-\mathrm{c}$ are immunoperoxidase staining, Figures 4d-e immunofluorescence. Panels a and d show a negative control antibody, panels b and e show IgD staining of the follicular mantle, and panels $\mathrm{c}$ and $\mathrm{f}$ show CD25 staining principally in the 
$4(\mathrm{e})$

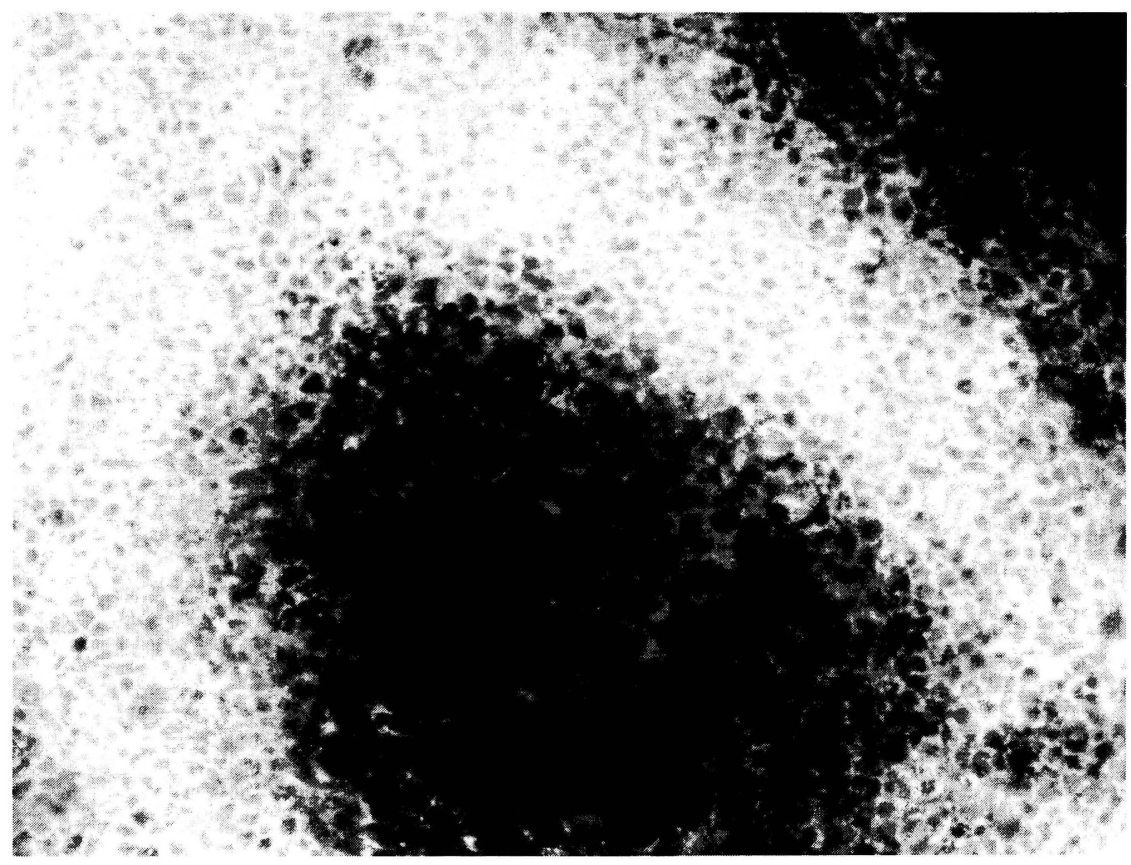

4 (f)

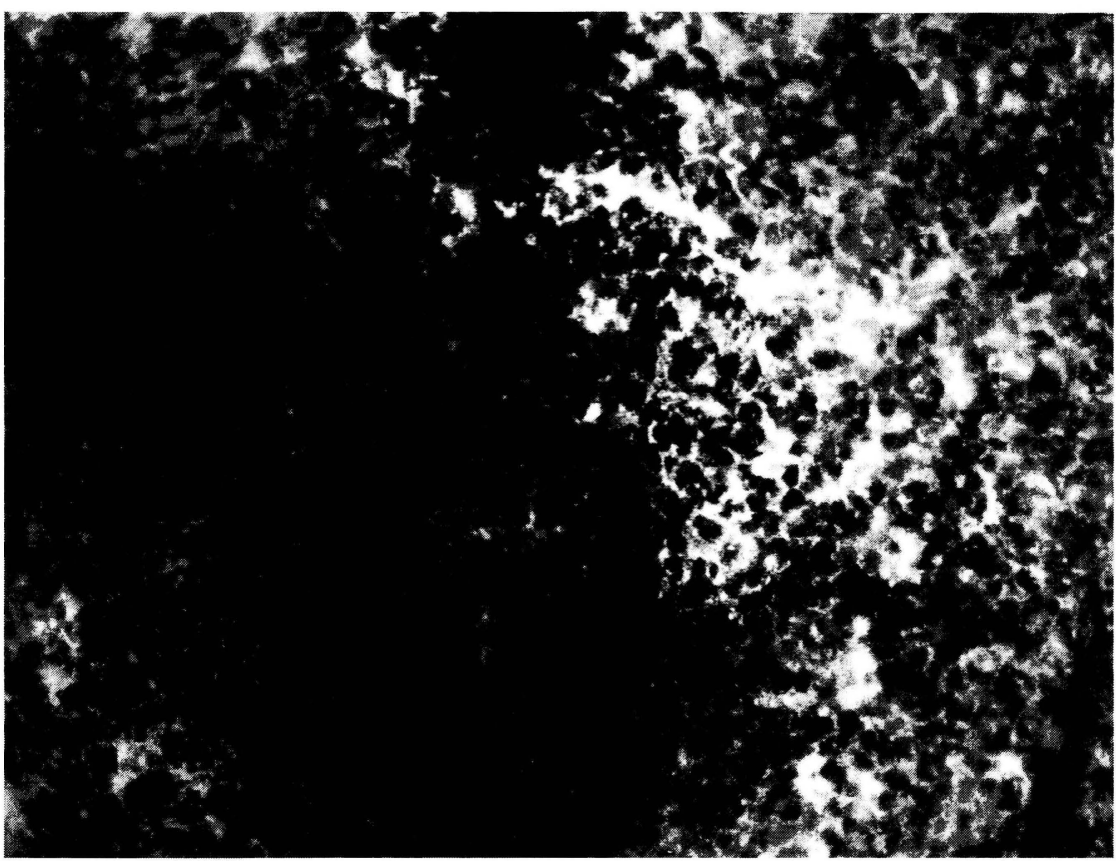

extrafollicular T cell zone. Panel $\mathrm{f}$ shows more widespread staining than seen in panel $\mathrm{c}$, although the most strongly-stained cells are seen by both methods. 


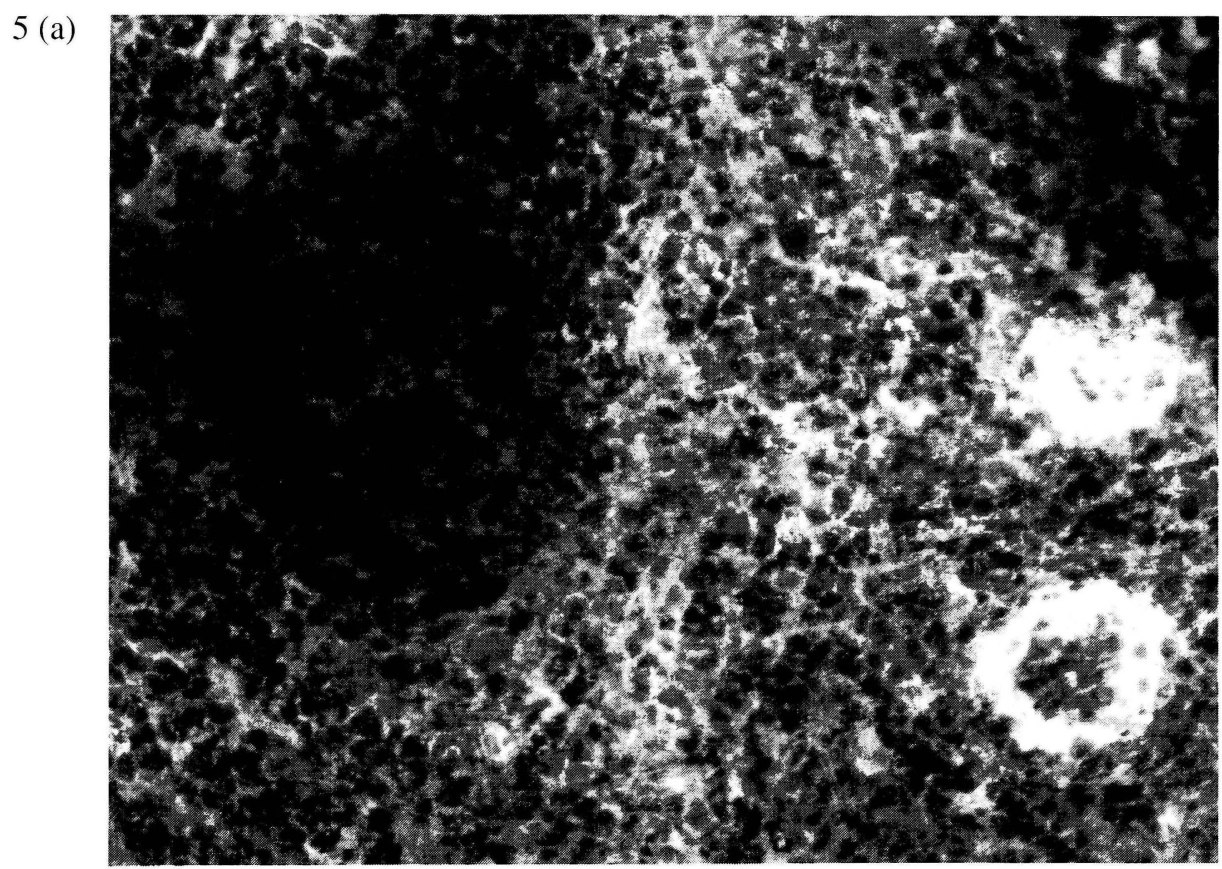

5 (b)

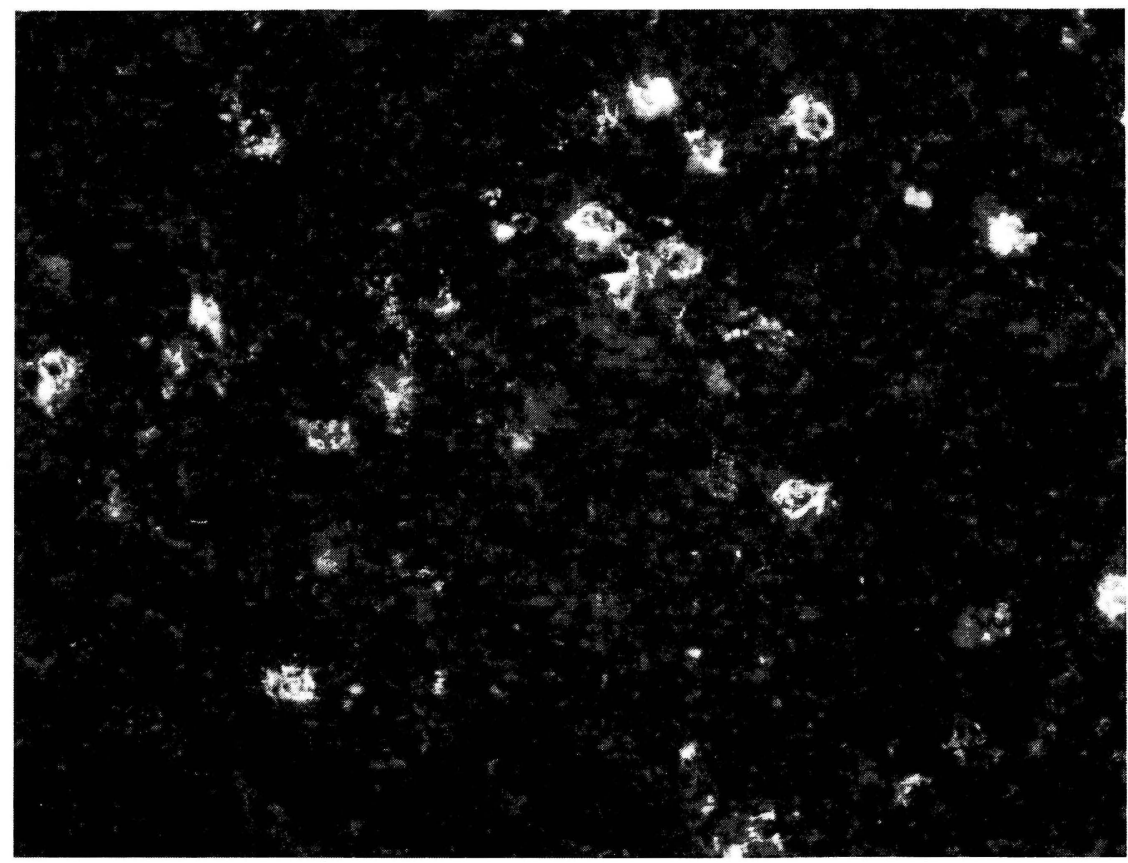

Figure 5. Examples of cytokine receptor expression in lymphoid tissue. See Tables 2 and 3 for detail. Figure 5a. IL-1 receptor (CD121a) on tonsil, showing staining of T cell zones around the germinal centre, which is unstained, and strong vessel endothelium staining. Figure 5b. c-kit on tonsil, showing brightly-stained cells 
5 (c)

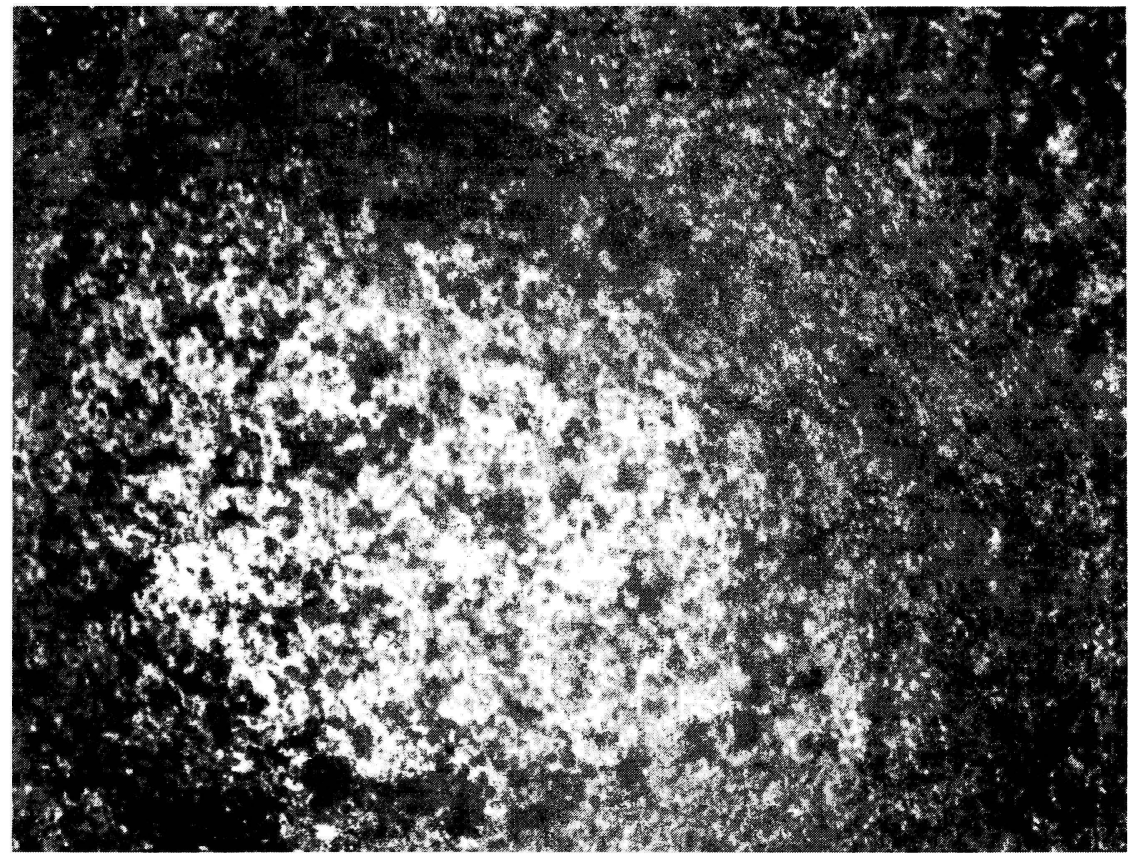

5 (d)

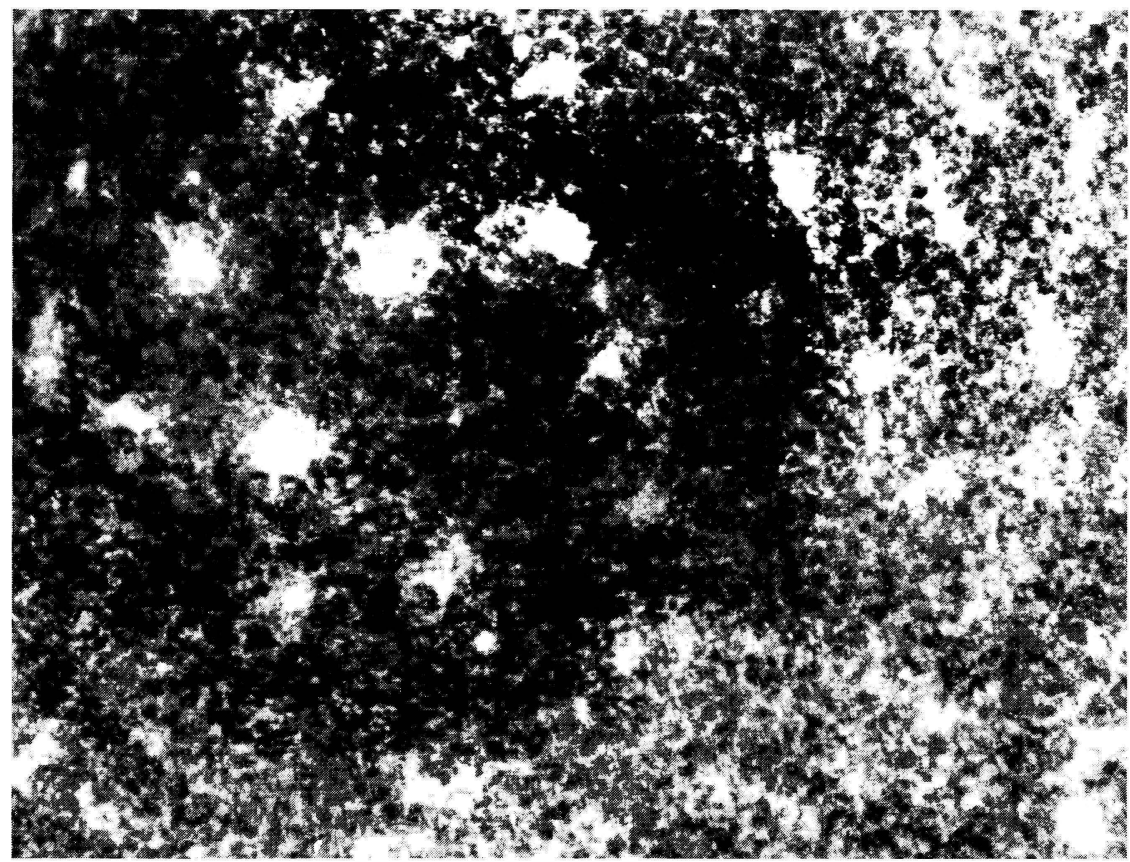

scattered through extrafollicular and connective tissue. Figure 5c. CD130 on spleen, showing staining principally in the germinal centre. Figure $5 \mathrm{~d}$. CD25 on gut-associated lymph-node tissue, showing scattered bright cells in germinal centre and surrounding $\mathrm{T}$ cell zone. 
negative, although weak staining was seen in one tonsil. Obvious staining of lymphoid areas, as well as bright staining of vessels, was also seen in the other lymphoid tissues. In suspension, however, no positive cells were seen in the lymphocyte population. c-kit was also not detected on lymphoid cells by flow cytometry, although in sections scattered brightly stained cells were seen in lymphoid areas (Figure 5b), and more abundantly in connective tissue. IL-4R (CDw124) was not seen in sections, although we have previously demonstrated weak staining of a proportion of tonsil $\mathrm{B}$ cells in suspension studies (16). The IL-6 receptor CD126 was seen at very low intensity in the GC and in extrafollicular areas. CD130, which together with CD126 forms the functional IL-6 receptor, stained more strongly, with preferential localization in the GC (Figure 5c). By flow cytometry (Figure 6) both CD126 and CD130 were associated primarily with IgDnegative, CD23-negative, CD38 -positive B cells, which are principally GC cells. CD130 stained vascular endothelium, though not as brightly as CD121a. IL-2 receptor staining was rather uniform for all three chains of the receptor, although CD25 showed stronger staining in T cell areas, with scattered bright cells in the T cell zone (Figure 4) and in the GC (Figure 5d). Flow cytometry showed no clear correlation with sub-populations (Figure 7).

\section{DISCUSSION}

The results presented show that immunofluorescence staining of tissue sections can give sensitivity comparable to flow cytometry for the detection of molecules expressed at low levels, in particular cytokine receptors. Some cytokine receptors were expressed at levels which precluded clear interpretation, but the sensitivity was generally greater than that achieved using immunoenzymatic methods and the method therefore provides an advance on existing techniques. Using high-sensitivity methods, the distribution of a number of cytokine receptors in secondary lymphoid tissue can be mapped and provides some interesting indications as to their function.

IL-1 receptor (Type I) was found associated with vascular endothelium and was expressed in the $\mathrm{T}$ cell areas of lymphoid tissues. Receptor expression on vascular endothelium has been described, based on studies of cells in suspension (Akeson et al., 1992; Colotta et al., 1993). Aortic endothelial cells were found to express 1000-3000 copies of the Type I receptor, and no Type II receptor (Akeson et al., 1992). IL-1 receptor on endothelial cells is functional, since IL-1 increases ICAM-1 expression on endothelial cells, and this can be blocked with antibody against the receptor (Akeson et al., 1992).

The fact that CD121a is detectable on tonsil sections but not in suspension studies is unlikely to be due to a difference in sensitivity, since other receptors were detected equally well by tissue and suspension studies (CD25) or with greater sensitivity in suspension (IL-4 receptor). We were not able to detect significant expression of IL-1R on circulating blood cells in an earlier study (Zola et al., 1993d). An alternative explanation is that the IL-1 receptor is stored intracellularly (and is thus accessible in sections but not on the cell surface) or that the receptor is lost from the cell surface during the processing of cell suspension. There is published evidence for shedding of the Type I receptor (Arend et al., 1994) and the Type II receptor (Colotta et al., 1993). The presence of IL-1R on mantle zone cells is particularly interesting in the light of the expression of membrane IL- $1 \alpha$ selectively in the follicular mantle and extrafollicular areas (Zola et al., 1993c). 

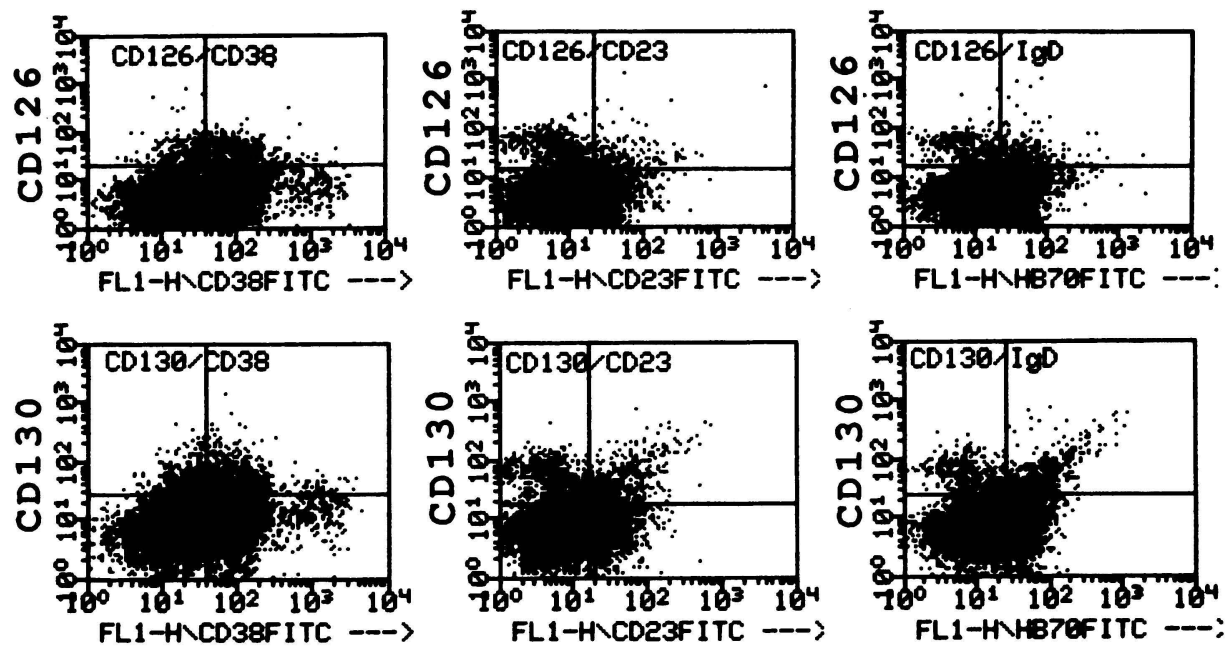

Figure 6. Two-colour analysis of CD126 (top row) and CD130 (bottom row) against B cell subset markers in tonsil: CD38 (primarily germinal centre cells), CD23 (primarily follicular mantle cells) and IgD (mantle and extra-follicular B cells).
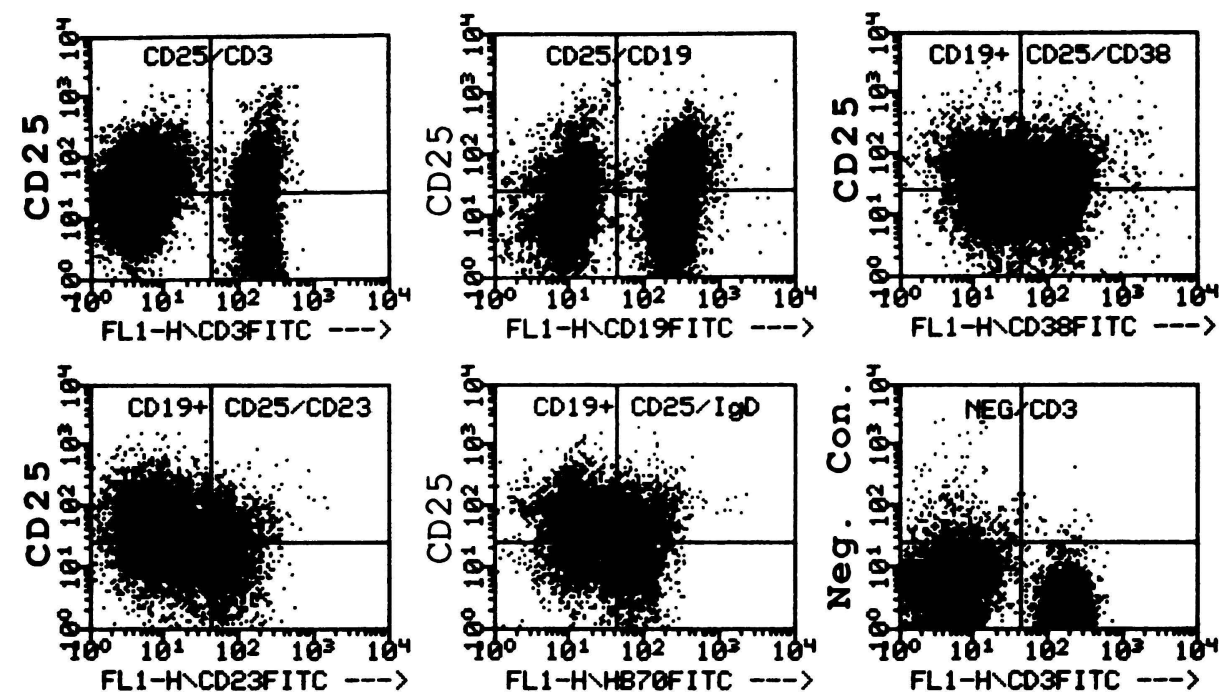

Figure 7. Three-colour analysis of expression of CD25. CD25 (vertical axis) is plotted against from left, top row: CD3 (T cell marker), CD19 (B cell marker), CD38 after gating for CD19-positive cells (B cells), bottom row from left: $\mathrm{CD} 23$ on gated $\mathrm{B}$ cells, IgD on gated B cells. The lower right figure shows a negative control antibody, isotype-matched for the CD25 antibody, against CD3. 
IL-2 receptors showed weak uniform staining throughout the lymphoid areas, with the $\alpha$ chain (CD25) showing somewhat stronger general staining in T cell areas, as well as a scattering of brightly-stained cells in T cell areas and GC. We have previously shown by high-sensitivity staining that IL-2R $\alpha$ and $\beta$ chains are expressed on a much larger population of cells than can be detected by conventional methods (Zola et al., 1989, 1990c), and the $\gamma$ chain is also quite broadly expressed in circulating cells (Ishii et al., 1994). The cells in tissue that express high levels of CD25, detectable as bright cells in immunofluorescence and also stained by immunoperoxidase, are likely to be activated cells, since CD25 has a rapid turnover (Sayar et al., 1990). Cells expressing lower levels of the 3 receptor chains are potentially responsive to IL-2, especially since IL- 2 can upregulate its own receptor (Waldmann, 1989).

IL-4 receptor was not detected by microscopy, although we have previously demonstrated expression of this receptor on a subset of B cells by flow cytometry (Zola et al., 1993a). This difference may be technical, although, as discussed above, there is no evidence for a systematic difference in sensitivity between our tissue section method and flow cytometric method.

IL-6 receptor gp80 (CD126) was seen at low level in the GC, and the gp130 signal transcution molecule (CD130) was also seen primarily in the GC, at significantly higher level. Although the difference in staining intensity for the two chains of the IL-6 receptor may simply reflect differences between the antibodies, it does suggest that GC cells may also use gp130 for one or more of the cytokines that share this signalling molecule, cilliary neurotrophic factor (CNTF), oncostatin M, leukaemia inhibitory factor (LIF) and IL-11. Once reagents are available, it would be interesting to examine the expression of the specific receptors for these molecules in $\mathrm{GC}$, and the functional role of the corresponding cytokines in the GC reaction. Autschbach et al. (1993) also found that CD130 was more broadly expressed than CD126; they attributed GC staining with CD130 to follicular dendritic cells. The role of IL-6 as a B cell differentiation factor active in late stages of differentiation (Kishimoto, 1989) would lead to the expectation of IL6 receptor expression on GC B cells, but we have found CD126 to be present at very low levels and often not detectable on tonsil GC cells, both in suspension and section studies. It may be that IL-6 acts later, after plasma cell precursors have left the GC.

IL-7 receptor and the two TNF receptors were detected at such low levels that interpretation of distribution would be unreliable. We have previously demonstrated strong expression of IL-7R on peripheral blood lymphocytes, but much lower expression on tonsil cells in suspension (Zola et al., 1993d). We also found TNF receptor Type I positive on circulating lymphocytes, particularly CD4 cells, but relatively poorly expressed on tonsil cells in suspension (Zola et al., 1993b). We have not been able to detect TNF receptor II on circulating or tissue lymphocytes (Zola et al., 1993d, 1993b).

Our understanding of cytokine action comes from a number of experimental avenues, most of them involving models well removed from physiological states. We know what cytokines can do, from in vitro activation experiments and from mice over-expressing the cytokines. We know something about the processes for which individual cytokines are essential, from knock-out mice and from "experiments of nature", but neither of these sources of information tells us reliably what cytokines do physiologically. Lymphoid tissues can provide important clues, because they contain resting cells, physiologically activated cells, cells in transit and cells localised in well-defined functionally interrelated areas. Studies of cytokine (Hoefakker et al., 1993; Andersson et al., 1994) or 
cytokine mRNA (Emilie et al., 1990) distribution in tissue have provided clues as to the physiological reactions that depend on cytokines. For example, the predominantly extrafollicular localization of cells producing IL-2, IL-4, IL-6 and IL-10 (Andersson et al., 1994; Emilie et al., 1990) suggest that the primary roles of these cytokines is not in the $\mathrm{GC}$, in spite of current models which suggest that class switching and B cell differentiation, processes that are thought of as being driven by these cytokines, occur in the GC. Receptor expression studies can provide essential complementary information to cytokine production data, and it is interesting that IL-2R was detected in the GC, but IL4 and IL-6R were negative or weak and variable respectively. The finding of IL-1R in the mantle and T cell area complements the demonstration (Andersson et al., 1994) of IL$1 \alpha$ in these same areas. We previously demonstrated by flow cytometry that membrane IL- $1 \alpha$ is specifically found on B cells with the phenotype of mantle zone cells (Zola et al., 1993c). The follicular mantle is generally thought of as a quiescent area, containing the un-stimulated remnants of the primary follicle. The co-expression of IL-1 and its receptor in the follicular mantle suggest a much more active role for mantle cells.

\section{ACKNOWLEDGEMENTS}

These studies were supported by grants from the Anti-Cancer Foundation of the Universities of South Australia and the Australian National Health and Medical Research Council. We are grateful to Dr. Charles Shih, PharMingen, San Diego, for the CD121a monoclonal antibody; Dr. M. Tsudo, Tokyo, for the CD122 antibody, and Professor K. Sugamura, Sendai, for the IL-2R $\gamma$ chain antibody. We thank Ms. Angela Neville and Dr. Brendon Coventry, University of Adelaide, for help and advice with immunoperoxidase staining, and Ms. Dimitra Beroukas, Flinders Medical Centre, Adelaide, for help with some tissue specimens.

\section{REFERENCES}

Akeson, A.L., Mosher, L.B., Woods, C.W., Schroeder, K.K., Bowlin, T.L. (1992). Human aortic endothelial cells express the Type I but not the Type II receptor for interleukin-1 (IL-1). J. Cell Physiol., 153, 583-588.

Andersson, J., Abrams, J., Bjork, L., Funa, K., Litton, M., Agren, K., Andersson, U. (1994) Concomitant in vivo production of 19 different cytokines in human tonsils. Immunology, 83, 16 24.

Arend, W.P., Maylak, M., Smith, M.F., Whisenand, T.D., Slack, J.L.. Sims, J.E., Giri, J.G., Dower, S.K. (1994). Binding of IL-1 $\alpha$, IL-1 $\beta$, and IL-1 receptor antagonist by soluble IL-1 receptors and levels of soluble IL-1 receptors in synovial fluids. J. Immunol., 153, 4766-4774.

Autschbach, F., Qiao, L., Wallich, R., Moubayed, P., Holl-Ullrich, K., Feller, A.C., Meuer, S.C. (1993). Immunohistochemical evaluation of cytokine receptor workshop antibodies. Tissue Antigens, 4, 329 (Abstract).

Berti, E., Soligo, D., Venegoni, L., Marzano, A., Lambertenghi Deliliers G. (1993). Immunohistochemical reactivity of cytokine receptor antibodies on normal and neoplastic tissues. Tissue Antigens, 42, 337 (Abstract).

Colotta, F., Re, F., Muzio, M., Bertini, R., Polentarutti, N., Sironi, M., Giri, J.G., Dower, S.K., Sims, J.E., Mantovani, A. (1993). Interleukin-1 Type II receptor: a decoy target for IL-1 that is regulated by IL-4. Science, 261, 472-475.

Coventry, B.J., Neoh, S.H., Mantzioris, B.X., Skinner, J.M., Zola, H., Bradley, J. (1994). A 
comparison of the sensitivity of immunoperoxidase staining methods with high-sensitivity fluorescence flow cytometry-antibody quantitation on the cell surface. J. Histochem. Cytochem., 42, 1143-1147.

De Weger, R.A., Van Gorp, J., Broekhuizen, R., Van Wichen, D.F., Klein, S. (1993). Immunohistochemical localisation of cytokine receptors in lymphoid tissues and Hodgkin lymphomas. Tissue Antigens, 42, 332 (Abstract).

Dower, S.K., Kronheim, S.R., March, C.J., Conlon, P.J., Hopp, T.P., Gillis, S., Urdal, D.L. (1985). Detection and characterization of high affinity plasma membrane receptors for human interleukin 1. J. Exp. Med., 162, 501-515.

Emilie, D., Peuchmaur, M., Maillot, M.C., Crevon, M.C., Brousse, N., Delfraissy, J.F., Dormont, J., Galanaud, P. (1990). Production of interleukins in human immunodeficiency virus-1replicating lymph nodes. J. Clin. Invest., 86, 148-159.

Hoefakker, S., van 't Erve, E.H., Deen, C., van den Eertwegh, A.J., Boersma, W.J., Notten, W.R., Claassen, E. (1993). Immunohistochemical detection of co-localizing cytokine and antibody producing cells in the extrafollicular area of human palatine tonsils. Clin. Exp. Immunol., 93, 223-228.

Ishii, N., Takeshita, T., Kimura, Y., Tada, K., Kondo, M., Nakamura, M., Sugamura, K. (1994). Expression of the IL-2 receptor gamma chain on various populations in human peripheral blood. International Immunology, 6, 1273-1277.

Kishimoto, T. (1989). The Biology of Interleukin-6. Blood, 74, 1-10.

Kondo, M., Takeshita, T., Ishii, N., Nakamura, M., Watanabe, S., Arai, K., Sugamura, K. (1993). Sharing of the interleukin-2 (IL-2) receptor gamma chain between receptors for IL-2 and IL-4. Science, 262, 1874-1877.

Kung, P.C., Goldstein, G., Reinherz, E.L., Schlossman, S.F. (1979). Monoclonal antibodies defiing distinctive human T cell surface antigens. Science, 206, 347-349.

Kuritani, T., Cooper, M.D. (1982). Human B cell differentiation. II. Pokeweek mitogenresponsive $\mathrm{B}$ cells belong to a surface immunoglobulin D-negative subpopulation. J. Exp. Med., 155, 1561-1566.

Lowenthal, J.W., Castle, B.E., Christiansen, J., Schreurs, J., Rennick, D., Arai, N., Hoy, P., Takebe, Y., Howard, M. (1988). Expression of high affinity receptors for murine interleukin 4 (BSF-1) on hemopoietic and nonhemopoietic cells. J. Immunol., 140, 456-464.

Noguchi, M., Nakamura, Y., Russell, S.M., Ziegler, S.F., Tsang, M., Cao, X., Leonard, W.J. (1993). Interleukin-2 receptor gamma chain: a functional component of the interleukin-7 receptor. Science, 262, 1877-1880.

Olweus, J., Lund-Johansen, F., Hoffman, R., Terstappen, L.W.M.M. (1993). Expression of cytokine receptors on haematopoietic progenitors examined by ultrasensitive flow cytometry. Tissue Antigens, 42, 334 (Abstract).

Rubin, L.A., Kurman, C.C., Biddison, W.E., Goldman, N.D., Nelson, D.L. (1985). A monoclonal antibody 7G7/B6, binds to an epitope on the human interleukin-2 (IL-2) receptor that is distinct from that recognized by IL-2 or anti-tac. Hybridoma, 4, 91-102.

Sayar, D., Ketzinel, M., Gerez, L., Silberberg, C., Reshef, A., Kaempfer, R. (1990). Expression of the Human IL-2 receptor on lymphoctyes involves rapid turnover of its p55 $\alpha$-subunit'(Tac) 1 . J. Immunol., 145, 2946-2949.

Taga, T. and Kishimoto, T. (1992). Cytokine receptors and signal transduction. FASEB J. 6, 33873396.

Tsudo, M., Kitamura, F., Miyasaka, M. (1989). Characterization of the interleukin 2 receptor beta chain using three distinct monoclonal antibodies. Proc. Natl. Acad. Sci. U.S.A., 86, 1982-1986.

Waldmann, T.A. (1989). The multi-subunit interleuking 2 receptor. Annu. Rev. Biochem., 58, 875-911.

Zola, H. (1992). Studies of cytokine receptor expression by cells of the immune system - A waste of time? Immunol. Today, 13, 419-420.

Zola, H. (1994). Detection of receptors for cytokines and growth factors. The Immunologist, 2, 47-50. 
Zola, H. (1995). Detection of cytokine receptors at the cell surface by flow cytometry. In: Coico, R. (Ed.), Current Protocols in Immunology, in press.

Zola, H., Flego, L. (1992). Expression of interleukin-6 receptor on blood lymphocytes without in vitro activation. Immunology, 76, 338-341.

Zola, H., Flego, L., Weedon, H. (1993a). Expression of IL-4 receptor on human T and B lymphocytes. Cell. Immunol., 150, 149-158.

Zola, H., Flego, L., Weedon, H. (1993b). Expression of membrane receptor for tumour necrosis factor on human blood lymphocytes. Immunol. and Cell Biol., 71, 281-288.

Zola, H., Flego, L., Wong, Y.T., Macardle, P.J., Kenney, J.S. (1993c). Direct demonstration of membrane IL- $1 \alpha$ on the surface of circulating B lymphocytes and monocytes. J. Immunol., 150, $1755-1762$.

Zola, H., Fusco, M., Flego, L., Donohoe, P.J., Macardle, P.J. (1993d). Expression of the cytokine receptor panel antibodies: high-sensitivity immunofluorescence studies on unstimulated cells. In: F. Schlossman (Ed.), Leucocyte Typing V. Oxford, Oxford University Press, in press (Abstract from Tissue Antigens, 42, 340).

Zola, H., Mantzioris, B.X., Webster, J., Kette, F.E. (1989). Circulating human T and B lymphocytes express the p55 interleukin-2 receptor molecule (TAC, CD25). Immunol. Cell Biol., 67, 233257.

Zola, H., Melo, J.V., Zowtyj, H.N., Nikoloutsopoulos, A., Skinner, J. (1990a). The leukocytecommon antigen (CD45) complex and B-lymphocyte activation. Hum. Immunol., 27, 368-377.

Zola, H., Neoh, S.H., Mantzioris, B.X., Webster, J., Loughnan, M.S. (1990b). Detection by immunofluorescence of surface molecules present in low copy numbers. High sensitivity staining and calibration of flow cytometer. J. Immunol. Methods, 135, 247-255.

Zola, H., Purling, R.J., Koh, L.Y., Tsudo, M. (1990c). Expression of the p70 chain of the IL-2 receptor on human lymphoid cells: Analysis using a monoclonal antibody and high-sensitivity immunofluorescence. Immunol. Cell Biol., 68, 217-224. 


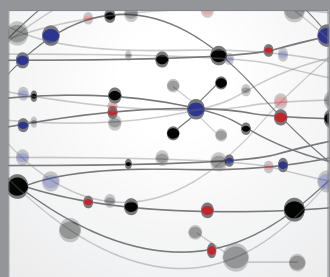

The Scientific World Journal
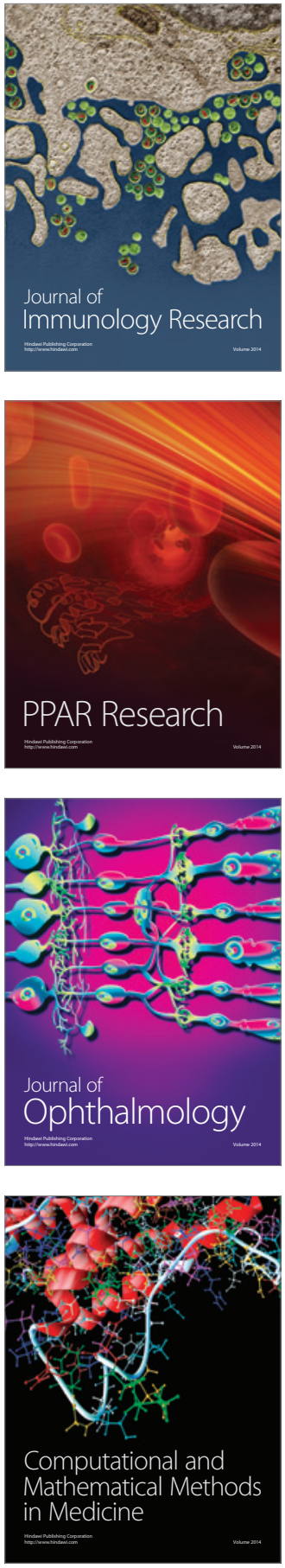

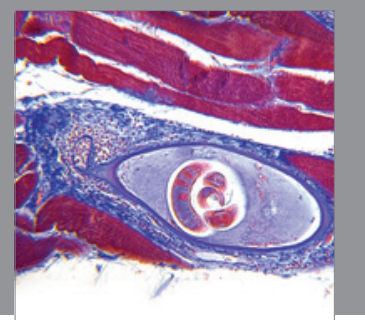

Gastroenterology

Research and Practice
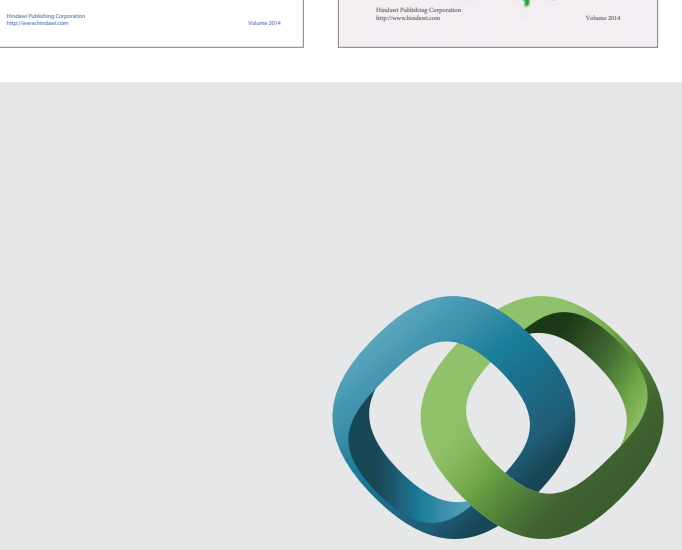

\section{Hindawi}

Submit your manuscripts at

http://www.hindawi.com
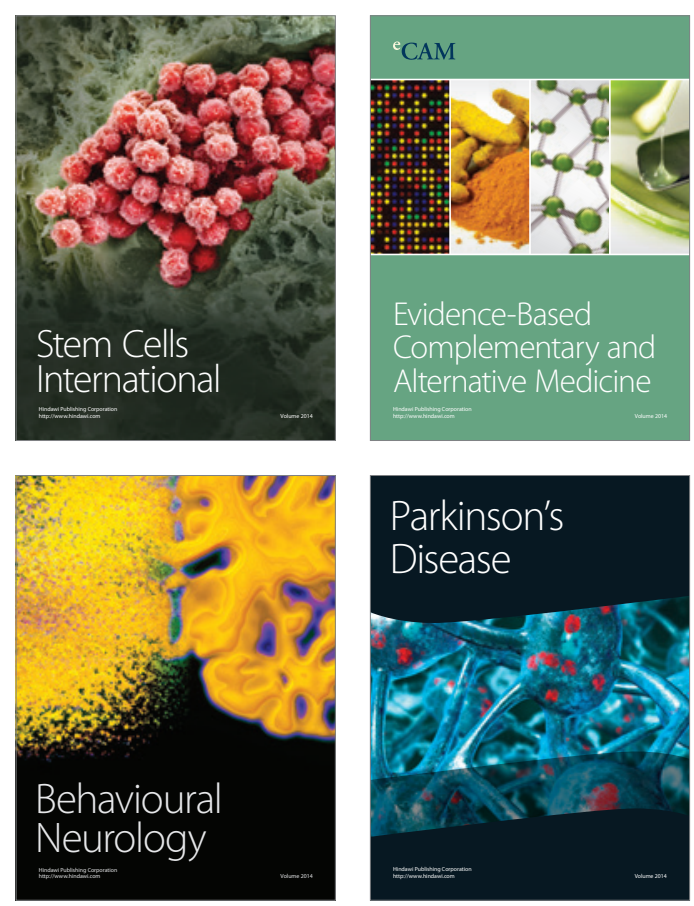

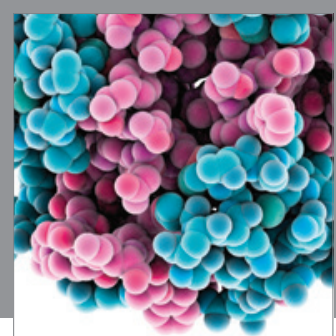

Journal of
Diabetes Research

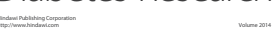

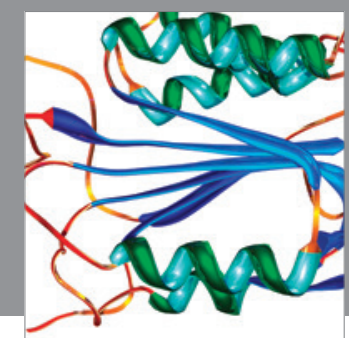

Disease Markers
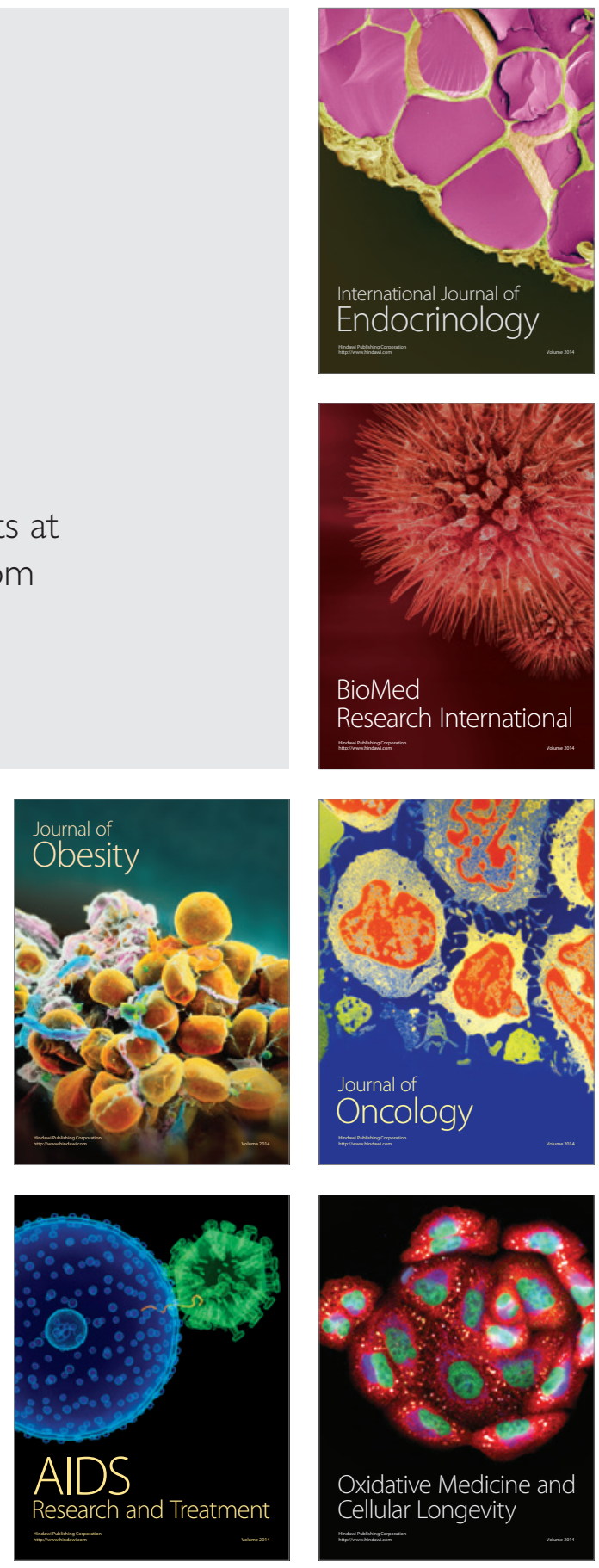